\title{
(Re)tradycjonalizm kaszubski: w stronę nowej ludowości
}

Streszczenie: W artykule podejmuję próbę rozpoznania nowej dla kaszubszczyzny praktyki (re)tradycjonalizmu, która rozpoznawana jest jako „nowa ludowość”. Najbardziej widoczną egzemplifikacją jest paradny strój ludowy i haft kaszubski, które estetyzują przestrzeń publiczną takich masowych imprez, jak Zjazdy Kaszubów czy Walne Zjazdy Zrzeszenia Kaszubsko-Pomorskiego. Przedmiotem eksploracji empirycznej są podręczniki do edukacji kaszubskiej. Na ich podstawie zrekonstruowałam wzory ludowości, za jej wyznacznik przyjmując „kaszubski paradny strój ludowy". Kontekstem interpretacyjnym jest koncepcja karnawału Michaiła Bachtina.

Słowa kluczowe: kultura kaszubska, kultura ludowa, karnawał, Michaił Bachtin, podręczniki, edukacja międzykulturowa

\section{Wprowadzenie}

Narody aby trwać, potrzebują spoiwa. Każdy z narodów wytwarza właściwe sobie jądro kulturowe (zazwyczaj zwane etnosem) i wokół niego konstruuje swe wyobrażenie o sobie. Narodowe wyobrażenia potrzebują zdarzeń/wydarzeń społecznych, aby uwiarygodnić siebie. Jednak to nie zdarzenie/wydarzenie społeczne ma moc narodowotwórczą, ale znaczenie, które wokół niego naród „wypracowuje”, i które musi być ideologicznie spójne z jądrem kulturowym. Czas może sprzyjać narodom, ale może też być ich wrogiem. Niekiedy narodom „udaje się” zachować przeszłe zdarzenia/wydarzenia pod postacią znaczeń. Stają się one wówczas przedmiotem społecznego pamiętania, wiedzy społecznej, historii narodowej (także w postaci zideologizowanej nauki i podręczników), mitów, a nawet tradycji, i tych dawnych, i tych nowych. Co ważkie, nie wszystkie zdarzenia/wydarzania społeczne są przechowywane, ale tylko te, które zaświadczać mogą o wielkości narodu. Inną sprawą jest to, czy wszystkie wielkie wydarzenia naprawdę miały miejsce w przeszłości 
narodu. Dla samego narodu nie jest to ważne. Ważne jest bowiem tylko to, co naród sam pamięta, że było, i w co wierzy.

Narody wypracowują szereg sposobów na to, by uczyć swe młode pokolenia, a starszym przypominać, o swej chlubnej i wielkiej przeszłości. Jednym ze sposobów jest formalna edukacja kulturowa (narodowa, etniczna, wspólnotowa itp.), innymi są sztuka i tradycja. W obrębie tej ostatniej wykorzystuje się obrzędy, zwyczaje, rytuały związane z celebracją różnego rodzaju świąt wspólnotowych. Tradycja to także przestrzeń ciągłych - jak to określił Eric Hobsbawm (2008, s. 10) - repetycji, „uprawianych” tylko po to, by utrzymać wrażenie, że przeszłość jest kontynuowana. Jeśli jednak uważnie prześledzić praktyki tradycji, to z dużym prawdopodobieństwem okaże się, że nie sięgają one czasów bajecznych i zamierzchłych, lecz wiele z nich lokuje swój początek w nie tak dawnych czasach. W przypadku Kaszubów nową tradycją są coroczne Zjazdy Kaszubów, pierwszy odbył się w 1999 r. w Chojnicach. Inną tradycją jest obchodzone od niedawna, bo od roku 2012, Święto Flagi Kaszubskiej (w dniu 18 sierpnia); nieco starszą; jest Dzień Jedności Kaszubów (19 maca), który celebrowany jest od roku 2004, na pamiątkę bulli papieża Grzegorza IX z 19 marca 1238 roku, w której znalazła się pierwsza pisemna wzmianka o Kaszubach. Tradycją „trochę” starszą są kaszubskie stroje ludowe i kaszubski haft. Swymi korzeniami sięgają one dwudziestolecia międzywojennego.

Wynajdywanie tradycji, bo o takim zjawisku w rzeczywistości mowa, nie jest tylko sprawą kaszubskiej wspólnoty/narodu ${ }^{1}$, ale jest częścią kulturowości każdego narodu. Zwykle narody dysponują zrównoważonym wzorcem swej kulturowości, ale kiedy następują w nim społeczno-kulturowe przesilenia, ich objawem może być wynajdywanie nowych tradycji, i budzić one mogą skrajne reakcje od akceptacji do odrzucenia (por. Hobsbawm, 2008).

Inspiracją dla tego tekstu jest kaszubskość, a właściwie nie cała kaszubskość, ale obserwowana w praktyce społecznej ekspansja ludowości, której wyznacznikiem są paradne stroje ludowe, hafty ludowe, muzyka, śpiewy i tańce ludowe. Praktyki te od kilkunastu lat także estetycznie waloryzują kaszubską przestrzeń publiczną, gdyż uludowiają takie imprezy masowe jak Zjazdy Kaszubów czy nawet Walne (Wyborcze) Zjazdy Zrzeszenia Kaszubsko-Pomorskiego. Uludowienie przestrzeni publicznej obserwowane jest także w przekazie, który proponuje uczniom edukacja kaszubska, co znajduje

1 Ze względu na spór środowiska kaszubskiego o to, czy Kaszubi są narodem, czy grupą etniczną, a może grupą regionalną, używać będę w artykule zapisu „wspólnota/ naród". 
odbicie w podręcznikach do edukacji kaszubskiej, i jest najbardziej widoczne w podręczniku Elżbiety Pryczkowskiej i Jadwigi Hewelt (Prëczkòwskô i Héwelt, 2015), który jest najmłodszy w tej grupie. Podręcznik posiada bogatą wizualną reprezentację ludowości, obrazowaną kaszubskim strojem ludowym. Na ten sam aspekt obrazowania kaszubskiej przestrzeni publicznej strojem ludowym zwraca uwagę Monika Mazurek (2010, s. 299), wprowadzając jednocześnie całkiem trafny termin „przebierania się w kaszubskość” dla próby opisu tego nowego (?) wzoru tożsamości kaszubskiej.

W artykule podejmuję próbę rozpoznania podręcznikowych wzorów kaszubskości i dopiero na ich podstawie rekonstruuję wzory ludowości kaszubskiej, której jednym z wyznaczników jest „kaszubski strój ludowy”. Jak pisałam, jest to najbardziej widoczny przejaw ludowości obserwowany w kaszubskiej przestrzeni publicznej. Ma on również swą intelektualną oraz wizualną reprezentację w podręcznikach. W kolejnym etapie, w celu rozpoznania genezy kaszubskiego stroju ludowego, rekonstruuję jego „dzieje”. Te trzy zrekonstruowane, kulturowe obszary kaszubszczyzny, a także użyta na sposób metodologiczny Bachtinowska koncepcja karnawału i kultury śmiechu, stanowić będą podstawę dla próby odpowiedzenia na pytanie o znaczenie/funkcję ludowości versus nowej ludowości dla trwania wspólnoty/narodu kaszubskiego.

\section{Podręcznikowe wzory wspólnoty/narodu kaszubskiego. Wybrane aspekty}

Podręczniki do edukacji kaszubskiej stanowią interesujący przedmiot badań z tego powodu, że pisane są przez Kaszubów, którzy jednocześnie byli/są nauczycielami edukacji kaszubskiej. Są one więc w swej warstwie kulturowej niczym innym jak intelektualną reprezentacją praktycznych wzorów kaszubskości, i jako takie stanowią obiektywizację aktualnie (dla momentu pisania podręcznika) praktykowanej i przeżywanej kaszubszczyzny.

Dyskursywna analiza podręczników daje możliwość rozpoznania ukrytej w nich skomplikowanej relacji wiedzy i władzy. Jeśli ująć podręczniki na sposób Foucaultowski, to pozwolą się one rozpoznać jako systemy powiązanych treści, a te - w myśleniu Michaela Foucaulta - są zjawiskami społecznymi. Dlatego też, jeśli badać podręczniki jako zjawiska społeczne, to z konieczności trzeba rozpoznać ich formułę pozytywną i jednocześnie negatywną. Oznacza to, że trzeba ujmować podręczniki nie tylko jako narzędzie wykluczania ze społeczeństwa, ale również jako instrument wytwarzania i re- 
produkowania względnie trwałej struktury społecznej (por. Foucault, 1993, ss. 30-31).

Mają więc podręczniki władzę nad człowiekiem, albo inaczej ujmując, mają moc wytwarzania jego tożsamości. Jako takie przejawiają naturę polityczną, gdyż wytwarzana przez nie wiedza społeczno-kulturowa i proponowany model zachowań społecznych decydują o świadomości. Tym samym podręcznik w imieniu władzy przejmuje kontrolę nad tożsamością młodego człowieka. Podręczniki to jedno z wielu narzędzi władzy i powodują one, że władza wnika w człowieka, przez to, że nasącza jego umysł określoną wiedzą i określoną ideologią (por. Foucault, 1993, ss. 32-33). Jak pisze Foucault, władza jest w tych, których zdominowała, i „(..) ich (b)lokuje, istnieje w nich i poprzez nich, ma w nich oparcie, tak samo jak oni w walce $\mathrm{z}$ nią opierają się na ujęciach, jakie im narzuca" (Foucault, 1993, 33) i dalej, Foucault tak pisze o najgłębszej naturze związku władzy-wiedzy: „władza produkuje wiedzę (...); (...) władza i wiedza wprost się ze sobą wiążą; (...) nie ma relacji władzy bez korelowanego z nimi pola wiedzy, ani też wiedzy, która nie zakłada i nie tworzy relacji władzy" (Foucault, 1993, s. 43).

Podręcznik przez sam fakt bycia podręcznikiem udowadnia, że reprezentowane w nim wizje człowieka i społeczeństwa są prawdziwe. I jako taki (re)orientuje człowieka na wspólnotowe wyobrażenia o sobie i swojej grupie społecznej. Inaczej ujmując, podręcznik powinien prywatne i osobiste wyobrażenia swoiście skorygować do wyobrażeń wspólnotowych. Jest to możliwe tylko wtedy, gdy podręcznik będzie potrafił wytworzyć przekonanie, że rzeczywisty świat wspólnoty/narodu jest właśnie taki jak ten ukazany w podręczniku.

Podręcznik jest nie tyle przekaźnikiem wiedzy społeczno-kulturowej, ale traktuje wiedzę w sposób instrumentalny. Chodzi w nim tylko o to, by nasączyć młodą tkankę społeczną określoną wizją rzeczywistości. W efekcie czego „(...) masy ludzkie - jak pisał Antonio Gramsci - dochodzą do konsekwentnego i jednoznacznego pojmowania współczesnej rzeczywistości (...)” (Gramsci, 1991, ss. 214-215).

Podręczniki do edukacji kaszubskiej z natury rzeczy pisane są więc w sposób typowy dla tego typu publikacji. Koncentrują się na tym, co jest realnie przeżywane przez daną wspólnotę/naród. Realne jest eksponowane w fizycznych przestrzeniach geograficzno-przyrodniczo-społecznych i psychospołecznych przestrzeniach codzienności. Taki zabieg jest konieczny, gdyż podręcznik powinien sprawiać wrażenie deskryptywnego wobec realnego życia dziecka. W rzeczywistości to, co realne, stanowi szkielet, do którego podpięte zostaje to, co ukryte, a co Ruth Benedict nazywa właśnie wzorem kultury. 
Ożywiona w podręczniku przestrzeń - dzięki ludziom - w świadomości dziecka stać się ma miejscem społecznym i kulturowym. Ukazana teraźniejszość także dzięki ludziom i ich sprawom zmienia się w codzienność. Jednak, co ciekawe, a co jest doskonale widoczne w badanych podręcznikach, miejsce i codzienność stają się dookreślonymi wymiarami życia ludzi, ale nie jednostek. Nie człowiek bowiem, ale ludzie tworzą wspólnotę/naród. Tak więc, to nie Kaszuba-człowiek, ale Kaszubi-wspólnota/naród tworzą kaszubskość w jej wymiarach kulturowym, społecznym i wspólnotowym/narodowym jednocześnie.

Ziemia, krew, dzieje, język, religijność, tradycja, ludzie i miejsca traktowane są przez autorów jako wyznaczniki tożsamości i znajdują swe reprezentacje w postaci wypisów z literatury kaszubskiej bądź w postaci tekstów pisanych dla podręcznika, a także w postaci wizualnej, jak fotografie, grafiki i rysunki. Podręcznikowe wskaźniki konstruowanej tożsamości są typowe dla wzorów tożsamości każdej innej wspólnoty/narodu. Zwrotnie stanowią one przejaw żywotnych potrzeb jednostek, gdyż są tym, co przemienia jednostkę w podmiot, a jednostki we wspólnotę/naród. W tej optyce nie ma większego znaczenia, czy jądro wspólnoty/narodu konstruowane jest na prawie ziemi, czy na prawie krwi. Chodzi o to, by wytworzyć i utrzymać przy życiu wspólnotę/naród, co oznacza konieczność wytworzenia w umysłach i emocjach poczucia wspólnotowości.

Podręczniki do edukacji kaszubskiej prezentują dwa podstawowe wzory kaszubskiej wspólnoty/narodu. Pierwszy jest konstruowany na prawie ziemi (Bòbrowsczi i Kwiatkòwskôko, 2007. Labudda, 2007. Labùdda, 2010. Czerwińska, Pająk i Sorn 2007a; 2007b; 2007c; 2009. Pająk i Sorn, 2015), drugi na prawie krwi (Pioch [2000], 2005, 2007, 2011a, 2011b, 2011c. Prëczkòwskô i Héwelt, 2015). Analiza treści podręczników uzmysławia jednak dość istotną zasadę, a mianowicie: ani prawo ziemi, ani prawo krwi nie potrafią samodzielnie wytworzyć poczucia wspólnotowości. Prawo ziemi i prawo krwi stanowią jądra właściwych sobie wzorów kaszubskości, ale są niewydolne, jeśli wziąć pod uwagę długie trwanie zbiorowości.

Dla wzoru kaszubskości konstruowanego na prawie ziemi edukacyjnie ważkie jest przesłanie, że (prze)trwanie Kaszubów jako wspólnoty/narodu możliwe jest tylko wtedy, gdy Kaszubi poznają swą kulturę, która jest wynikiem ich związania z ziemią kaszubską. I jednocześnie wezmą odpowiedzialność za swą kulturę, bo będzie to znaczyło, że stali się oni odpowiedzialni za siebie jako wspólnota/naród. Stąd też odzwierciedleniem takiej kaszubszczyzny jest równanie: ziemia-wspólnota/naród-kultura. 
Dla wzoru kaszubskości konstruowanego na prawie krwi rozpoznać można dwa warianty. We wzorze narodu/wspólnoty kaszubskiej, który prezentują podręczniki Danuty Pioch ([2000], 2011b, 2011c) edukacyjnie ważka jest teza, że kaszubskość to sprawa rodowa. (Prze)trwanie Kaszubów jako wspólnoty/narodu jest możliwe dlatego, że kaszubskość dziedziczona jest w linii męskiej. Kaszuba to zatem ktoś, kto ma ojca Kaszubę i matki Polki. W ten sposób dziedziczy się język (od ojca Kaszuby?) i wiarę (od matki Polki?), a to determinuje codzienność Kaszubów. Ten wzór kaszubszczyzny buduje się na równaniu: krew-wspólnota/naród-język i wiara.

Dla wzoru kaszubskości konstruowanego na prawie krwi w podręcznikowej koncepcji Pryczkowskiej i Hewelt (Prëczkòwskô i Héwelt, 2015) edukacyjnie znaczące jest przekonanie, że kaszubskość to sprawa familii, które ukochały swą kaszubską ojczyznę. Jest ona - kaszubskość - nade wszystko sprawą krwi familijnej. Kaszubszczyzna przeżywana jest wewnątrz rodzin we wspólnych tańcach, pieśniach, muzykowaniu i graniu w karty. Ludowość jest tym, co spaja i wytwarza więzi, i tym, co obok familijności pozwala manifestować w przestrzeni publicznej afekt dla kaszubskiej ojczyzny. Taki wzór kaszubszczyzny daje się ująć w zdaniu: krew-wspólnota/familia-ludowość (por. Kożyczkowska, 2016).

\section{Ludowość versus nowa ludowość}

Ostatni z pokrótce omówionych podręczników (Prëczkòwskô i Héwelt, 2015) prezentuje wizję ludowości kaszubskiej, którą rozpoznać można także w publicznej przestrzeni Kaszub, na co zwróciłam już uwagę we wstępie artykułu. Podręcznik nie tylko stanowi intelektualną reprezentację ludowego wyobrażenia kaszubszczyzny, ale dodatkowo - zwrotnie - wzmacnia ją w przekazie edukacyjnym. Jednocześnie, co muszę podkreślić, ludowość jest obecna także w innych przywołanych wyżej podręcznikach. Jest ona elementem wzoru kaszubszczyzny konstruowanego na prawie ziemi, i jest obecna także w koncepcji Pioch, w jej podręcznikowym wzorze kaszubskości konstruowanym na więzach krwi rodowej.

W przypadku wzoru kaszubskości, który konstruowany jest na więzach ziemi, ludowość wyraźnie wiązana jest z przeszłością. Na wzór przeszłości składają się także elementy historyczne, czyli ważkie zdarzenia z historii Kaszub, w powiązaniu z osobami i miejscami, ale też wprost przedstawiane są kaszubskie autorytety (np. twórcy literatury). Pojawia się wiedza o obrzędach (np. świątecznych), tradycji (np. postać gwiazdora), tradycyjnej sztuce ludo- 
wej i użytkowej (hafty, ceramika, rzeźba), a także o tradycyjnych rzemiosłach kaszubskich (wikliniarstwo).

Ludowość wpisana w poczet artefaktów przeszłości jest jednak jednoznacznie powiązana z życiem codziennym wsi, lecz takiej, która już nie istnieje, ale można uzyskać do niej dostęp przez wiedzę, którą oferuje m.in. skansen we Wdzydzach. To najlepiej obrazuje elementarz Witolda Bobrowskiego i Katarzyny Kwiatkowskiej (Bòbrowsczi i Kwiatkòwskôko, 2007, ss. 10-11, ss. 128-129). Przy opisie skansenu wdzydzkiego autorzy prezentują po raz pierwszy w podręczniku paradny strój ludowy, w jego wersji opracowanej dla kartuskiego zespołu folklorystycznego. Wizualna oprawa dla tych treści wyraźnie scala paradny strój ludowy i wdzydzkie eksponaty (chałupy, wiatrak, kościół). Podręcznik - w treści pisanej - także jednoznacznie wskazuje, że chodzi tu o ludowość, która istnieje już tylko w muzeum (Bòbrowsczi i Kwiatkòwskôko, 2007, ss. 10-11). Kontynuacja wątku kaszubskiego stroju ludowego pojawia się w temacie „Kaszëbsczi festiwal [Kaszubski festiwal]” (Bòbrowsczi i Kwiatkòwskôko, 2007, ss. 128-129), i jest on po raz ostatni w tym podręczniku prezentowany. Tym jednak razem strój ludowy powiązany jest z estradą i występami zespołów folklorystycznych, które „na festiwal" przybyły z różnych regionów Kaszub, co potwierdza oprawa wizualna tematu. Postacie na ilustracji tańczą i są ubrane w estradowe stroje ludowe z różnych części Kaszub.

Podobnie - z tradycją - łączony jest strój ludowy w podręcznikach Jaromiry Labuddy (2007; Labùdda, 2010). W jej obu podręcznikach znaleźć można tylko dwie wizualne reprezentacje: pierwsza jest oprawą opowiadania Alojzego Negla „Cëdowny wzérnik [Cudowny telewizor]” (Labùdda, 2010, 170), druga - dla opisu typowo kaszubskiego zwyczaju „ścinania kani”2 (Labùdda, 2010, 179). W przypadku podręczników pomocniczych Teresy Czerwińskiej, Aleksandry Pająk i Lucyny Sorn (2007a; 2007b; 2007c; 2009. Pająk i Sorn, 2015) strojowi kaszubskiemu poświęcona jest tylko jedna lekcja w podręczniku do klasy II. I jednoznacznie autorki podpisują dwa rysunki do kolorowania: „dziewczęcy strój kaszubski” i „chłopięcy strój kaszubski” (Czerwińska, Pająk i Sorn, 2007b, ss. 11-12).

2 Zwyczaj ścinania kani towarzyszy obrzędowości świętojańskiej. Ptak kania jest symbolem zła i - właśnie jako symbol zła, prawdopodobnie ku przestrodze - musi zostać stracony (czyli ścięty). Logika ceremonii osadzona jest na idei wspólnotowości. Zło bowiem dotyka całą wspólnotę (a nie - jak można sądzić - pojedynczego człowieka), stąd też rytualne oczyszczenie (zabicie kani) to sprawa wszystkich (Więcej: Rompski, 1973. Treder, 2012). 
Ludowość, która pojawia się w podręcznikach współautorów Bobrowskiego i Kwiatkowej, autorki Labuddy, a także współautorek Czerwińskiej, Pająk i Sorn, nie przeciąża podręcznikowych wzorów kaszubszczyzny. Jest ona istotna, gdyż jest jednym z wyznaczników tożsamości kaszubskiej, ale - jak przekonują podręczniki - w codziennym życiu Kaszubi swym ubiorem i zachowaniem nie różnią się od Polaków i przedstawicieli innych narodowości.

Ludowość eksponowana przez kaszubskie stroje ludowe w podręcznikach Pioch ma swoje dwie odsłony. Pierwsza - znamionuje cykl podręczników „Üczbòwnik do kaszëbsczégò jãzëka” (Pioch, [2000]; 2005; 2007), które były wydawane do 2007 r., i podręcznika do gimnazjum „Òjczëstô mowa” (Pioch, 2011a). Druga odsłona - to wizualna i tekstowa prezentacja ludowości, która pojawia się w nowszych podręcznikach „Z kaszëbsczim w swiat” (Pioch, 2011b) i „Kaszëbë. Zemia i lëdze. U̇czbòwnik do kaszëbsczégò jãzëka” (Pioch, 2011c), oba z 2011 roku.

Odsłona pierwsza ludowości w podręcznikach Pioch, wyrażona przez strój ludowy, pojawia się tylko w trzeciej części autorskiego cyklu „Üczbòwnik do kaszëbsczégò jãzëka”. Strój ludowy jest prezentowany w tematach „Etniczné podgromadë Kaszëbów [Etniczne podgrupy Kaszubów]” (Pioch, 2005, ss. 94-95), i „Chłopsczé i białogłowsczé ruchna [Męska i kobieca odzież]” (Pioch, 2005, ss. 96-97). Dla zilustrowania obu tematów użyto paradnej wersji kaszubskiego stroju ludowego. W treściach tematu drugiego autorka dokonała zestawienia tytułu „Chłopsczé i białogłowsczé ruchna” i fotografii kobiety oraz mężczyzny w paradnym stroju ludowym. Jest to istotny zabieg metodologiczny z punktu widzenia interesującej mnie problematyki, gdyż tytuł i fotografia stanowią wzajemnie dla siebie konteksty, to zaś wzmacnia przekonanie, że strój ludowy to ubranie Kaszubów, które ci noszą codziennie dlatego, że są Kaszubami.

Jednak w temacie „Chłopsczé i białogłowsczé ruchna” Pioch dostarcza uczniom wiedzy na temat kaszubskich strojów ludowych, co równoważy wytwarzane przekonanie, że Kaszubi na co dzień noszą stroje ludowe. Otóż autorka pisze:

„Kaszubi mieli swe pierwsze ubrania, którymi różnili się od innych mieszkańców. Dziś do końca nikt nie wie, jak ta historyczna odzież wyglądała. To, co noszą dziś osoby należące do zespołów folklorystycznych albo Kaszubi z okazji ważnych wydarzeń, nie do końca wygląda tak, jak w przeszłości.

Aby poznać kaszubski strój i nazwać każdą z jego części z osobna, najlepiej byłoby pójść do muzeum, których na Kaszubach nie brakuje [podkreślenia - A.K.]" (Pioch, 2005, s. 97). 
Pioch dostarcza zatem uczniom kulturowo istotnej wiedzy, pomaga uporządkować społeczno-kulturową wiedzę uczniów, która rozdziela folklor i estradę od muzeum a także folklor, estradę i muzeum od codziennego i zwyczajnego życia. I kolejna kwestia w tym przekazie, pojawia się tu implicite informacja, że wiedza o własnej kulturze może mieć także obszary nie-wiedzy (owo: „dziś do końca nikt nie wie...”). I choć autorka nie wyjaśnia skąd wziął się kaszubski strój ludowy w takiej wersji, która jest prezentowana w podręczniku, to jednak cykl podręczników „Üczbòwnik do kaszëbsczégò jãzëka” nie konstruuje przeświadczenia, że w codzienności Kaszubi takich strojów używają. Z kolei podręcznik do gimnazjum „Òjczëstô mowa” w ogóle nie podejmuje tematyki stroju ludowego.

Ludowość w tej grupie podręczników jest prezentowana jako część tradycji, a nawet część przeszłości, która jest tak samo ważna jak inne sprawy tożsamościowe, ale należy do przeszłości. Ukrytą zasadą podręcznika jest to, by uczeń otrzymał rzetelną wiedzę na temat omawianych społecznych zachowań i artefaktów kulturowych.

Odsłona druga ludowości w koncepcji Pioch, w późniejszych jej podręcznikach, charakteryzuje się zmianą strategii prezentowania treści ludowych. Nie jest to już poznanie przez dostarczanie rzetelnej wiedzy o prezentowanych w podręcznikach ludowych elementach kultury. Być może jest to efekt obserwowanego wtargnięcia ludowości w postaci stroju ludowego w kaszubską przestrzeń publiczną i jej zawłaszczenia, co rozpoznać można przez ludową estetyzację przestrzeni publicznej. Zjawisko to jest rozpoznawalne w podręczniku „Kaszëbë. Zemia i lëdze. Ùczbòwnik do kaszëbsczégò jãzëka” (Pioch, 2011c). Na sześciu jego stronach pojawiają się grafiki, których treścią są postacie w kaszubskich strojach ludowych. Wiek postaci wskazuje nie tylko pokoleniowość kaszubskiej rodziny, ale też sugeruje, że paradny albo roboczy strój ludowy są właściwym ubiorem dziadków (Pioch, 2011c, ss. 15, 20, 30, 31, 138, 167), rodzice swą garderobę komponują z elementów stroju ludowego, a dzieci mają ubrania zwyczajne (Pioch, 2011c, ss. 30, 31) lub z kaszubskim herbem (Pioch, 2011c, s. 20). Jeśli jednak „akcja” grafiki rozgrywa się na wsi, to nie tylko dziadek, ale i dzieci są w strojach ludowych (Pioch, 2011c, s. 167). Czytając podręcznik, trudno wyzbyć się wrażenia, że paradny albo roboczy strój ludowy to właściwe przyodziewki Kaszubów, za pomocą których można ich odróżnić od nie-Kaszubów. Przeświadczenie to konstruuje celowe zestawianie tekstu z oprawą graficzną. Przykładowo autorka pyta: „Kogo można nazwać Kaszubą? Jaki on musi być, jak wyglądać? Czy ty też jesteś Kaszubą? [podkreśl. - A.K.]” i zamieszcza pod pytaniami 
grafikę, na której znajdują się starsze wiekiem osoby - kobieta i mężczyzna - w kaszubskich strojach ludowych (Pioch, 2011c, s. 15).

Ludowość podręcznikowych wzorów wspólnoty/narodu kaszubskiego nie musi być odzwierciedlona wyłącznie w paradnych strojach ludowych, ale może pojawiać się również w swej „nowoczesnej” wersji, którą Pryczkowska i Hewelt nazywają "nowoczesnym dizajnem”. „Nowoczesny dizajn” jest wersją dedykowaną bardziej postępowym Kaszubom. W konsekwencji ludowość i postępowa ludowość są tym, co estetyzuje wizualną przestrzeń Kaszub, jak wynika z podręcznika autorek (Prëczkòwskô i Héwelt 2015, s. 158). Nowoczesny „dizajn” to jeden z obszarów podręcznikowej uludowionej kaszubszczyzny, który zdaje się wynikać z dwóch przesłanek: z tego, że turyści „chcą ludowych pamiątek” (Prëczkòwskô i Héwelt, 2015, ss. 154-155), i z tego, że Kaszubi - jak wynika z wizualnej oprawy podręcznika - „chcą” ubierać się w kaszubskie, paradne stroje ludowe.

Drugi z podręcznikowych obszarów uludowienia kaszubszczyzny wiąże się z jej sprowadzeniem do tzw. kultury śmiechu. Pryczkowska i Hewelt, słowami Stanisława Janke, z wywiadu udzielonego Piotrowi Lessnau (2007, s. 7), piszą, że Kaszubi mają „bardzo zdrowe podejście do śmiechu, humoru, radości i jest to w całej literaturze [kaszubskiej - uwaga A.K.] bardzo mocno widoczne. I nawet dość duża część ludzi ma takie myślenie związane z kaszubszczyzną, że kaszubszczyzna to jest coś »trochę do śmiechu «" (Prëczkòwskô i Héwelt, 2015, s. 184). Stąd zapewne - jak wynika z tytułu ostatniego tematu w książce - „Kultura Kaszub” jest jak „[z] uśmiechem przez życie” (Prëczkòwskô i Héwelt, 2015, s. 153).

Trzeci obszar uludowienia kaszubszczyzny jest rozpoznawalny przez warstwę wizualną podręcznika. Podręcznik przesycony jest fotografiami, na których znajdują się osoby w kaszubskich, paradnych strojach ludowych. Przesycenie dostrzec można również w nagromadzeniu fotografii, na których znajdują się osoby w ubraniach opatrzonych albo godłem kaszubskim, albo barwami flagi kaszubskiej, albo też są one przykryte/okryte flagą kaszubską. Na blisko 300 fotografii z wizerunkami ludzi aż 40 to fotografie osób, które ubrane są w stroje ludowe, a kolejne 20 to fotografie przedstawiające osoby we wspólnotowej/narodowej symbolice kaszubskiej. Zatem - co łatwo policzyć - 1/5 fotografii przedstawia ludzi przebranych w kaszubską symbolikę ludową lub w kaszubską symbolikę wspólnotową/narodową.

Podręcznik konstruuje przekonanie - dzięki swej warstwie wizualnej że Kaszubi to taka społeczność, która często ubiera się w stroje ludowe lub wspólnotowe/narodowe. Wystarczy zatem przyjechać na Kaszuby i istnie- 
je duża szansa, że takich „przebranych na ludowo”, albo „przebranych na wspólnotowo/narodowo” Kaszubów się spotka. Podręcznik specyfikuje wiedzę o Kaszubach i przedstawia ich życie na sposób radosny, z uśmiechem: w tańcu, w śpiewie, w muzykowaniu (w grze na akordeonie), na łonie familii, albo na estradzie. Jedni Kaszubi występują w zespołach folklorystycznych i tu kultywują kulturę ludową, inni występują w show biznesie, a pozostali produkują i handlują pamiątkami ludowymi, bo przecież turyści chcą je kupować. Najbardziej czczonymi twórcami kultury kaszubskiej są autorzy śpiewników, a sami Kaszubi albo śpiewają, albo „serfują” po internecie i szukają w nim inspiracji na kaszubski biznes. Tyle tylko i aż tyle trzeba zrobić, by kultura kaszubska przetrwała. Tyle tylko i aż tyle wystarczy, by pokazać i by udowodnić, że kocha się swą kaszubską ojczyznę. Tyle tylko i aż tyle trzeba zrobić, by udowodnić, że kaszubszczyzna jest „trochę do śmiechu”.

Chociaż podręcznik przesycony jest fotografiami osób w kaszubskich strojach ludowych, to nie omawia ich znaczenia i nie przybliża ich historii. Innymi słowy, autorki nie zadały sobie trudu wyjaśnienia uczniom tych zawiłych kwestii, przez co dostarczają określonej wiedzy o kaszubszczyźnie, której zasobem jest familia, zabawa i przebranie w strój ludowy lub wspólnotowy/narodowy.

Podręcznik Pryczkowskiej i Hewelt ukazuje Kaszubów jako wspólnotę/ naród, której codzienność jest przesiąknięta symboliką ludową i wspólnotową/narodową. Paradny strój ludowy staje się wizualnym narzędziem dekonstrukcji kaszubskiej przestrzeni publicznej i alternatywą dla tradycyjnej kultury ludowej, w której jeszcze do niedawna nie było strojów ludowych, jeśli rozumieć je tak, jak je przedstawiają Pryczkowska i Hewelt.

\section{Kaszubszczyzna to jest coś „trochę do śmiechu”: uwagi metodologiczne}

W pewnym sensie Pryczkowska i Hewelt sugerują, że kaszubszczyzna istnieje dzisiaj, przynajmniej w niektórych społecznościach kaszubskich, jako kultura śmiechu. Bo jeśli kaszubszczyzna to jest coś „trochę do śmiechu”, a „kultura Kaszub” jest jak „z uśmiechem przez życie”, zaś Kaszubi chętnie przebierają się w paradne stroje ludowe, to autorki dostarczają zasadnych argumentów, by interpretować ich wizję kaszubskości jako skarnawalizowaną kaszubskość.

Karnawał jest przecież niczym innym jak formą obrzędowo-widowiskową (Bachtin, 1975, s. 218) i jednocześnie jest elementem folkloru ludowego (Bachtin, 1975, s. 222). Pryczkowska i Hewelt dają wiele wskazówek do tego, 
aby badać ich podręcznik przy użyciu myślenia Michaiła Bachtina. Najbardziej znaczące w takim wyborze działania metodologicznego jest to, że jeśli zestawić koncepcję świata kaszubskiego wedle Pryczkowskiej i Hewelt z koncepcją świata kaszubskiego wedle Pioch, to dostrzec można, że ich wspólnym jądrem jest prawo krwi. Różnica jest jednak zasadnicza, ponieważ w myśleniu Pryczkowskiej i Hewelt idzie o krew familijną, a w myśleniu Pioch idzie o krew rodową. Pierwsze silnie ciąży ku teraźniejszości, drugie ku przeszłości. Z tego wynika dalsza różnica między koncepcjami, i jest ona efektem autorskich propozycji tego, co ma edukacyjnie wiązać wspólnotę/naród kaszubski. We wzorze Pryczkowskiej i Hewelt jest to ludowość wytwarzana tu i teraz, i przeżywana radośnie w codzienności. We wzorze Pioch jest to wiara i język, które są wyraźnie odziedziczone z przeszłości przez matkę i ojca, i przeżywane wzniośle w codzienności.

Ludowość przybiera w podręczniku Pryczkowskiej i Hewelt postać radosnego karnawału, który przeżywany jest familijnie. Potrzebuje on przebrań (strojów ludowych lub narodowych/wspólnotowych), procesji (Zjazdy Kaszubów), familijnych spotkań (tańców, śpiewów, muzykowania, gry w karty) i estradowych występów. W porównaniu z wzorcem Pioch, który przeciążony jest poważną kaszubską religijnością i atencją dla języka, podręcznikowa ludowość Pryczkowskiej i Hewelt jest jak Bachtinowski świat karnawału. Ze swoją prawdą o kaszubszczyźnie i ze swą niezgodą na kaszubszczyznę w propozycji elit wykształconych i/lub pobożnych, autorki stają się adwokatkami innej, bo karnawałowej kaszubszczyzny, tym samym afirmują podwójność świata kaszubskiego.

Na podwójność świata zwraca uwagę myślenie Bachtina, wtedy gdy konstruuje on swą koncepcję karnawału. Karnawałowa podwójność świata wynika z istniejącej w karnawale swoistej opozycji wobec „rzeczywistości oficjalnej" (tu: rzeczywistości intelektualnych i/lub pobożnych elit kaszubskich) i/a „drugiego świata i drugiego życia” (tu: rzeczywistość ludu kaszubskiego, czyli zwyczajnych Kaszubów). Bachtin przekonuje, że „dwoistość percepcji świata” i „dwoistość życia” to stałe wymiary i kultury, i życia. Wynika to nie tyle z ich warstwowości, ale z podwójności, a właściwie z opozycji powagi - śmiechu i obelżywości, a nawet z opozycji bohaterów (tu: autorytety twórcy literatury kaszubskiej) - „parodystycznych sobowtórów-dublerów” (tu: autorytety - twórcy śpiewników kaszubskich) (Bachtin, 1975, s. 62). Świat powagi i świat śmiechu nie muszą być jednak wobec siebie w opozycji - w ścisłym znaczeniu tego słowa - ale można je pojmować także jako dwa aspekty świata: powagi i śmiechu. Współistnieją one i nawzajem się od- 
zwierciedlają. I równocześnie są one całościowe, lecz nie są odrębne. Nie są pojedynczymi obrazami, które są albo komiczne, albo poważne (Bachtin, 1975, s. 203). Dlatego jak się wydaje, nie można zjawiska karnawalizacji kultury kaszubskiej badać w oderwaniu od tego, co wiąże się z kaszubszczyzną nurtu oficjalnego. Taki trop metodologiczny zdaje się słuszny, gdyż - jak pisze Bachtin - w badaniach istoty karnawału trzeba się odnieść także do całościowego obrazu powagi. Jest to konieczne pomimo technicznych aspektów karnawału, do których należą jego jarmarczno-uliczna otwarta formuła zapraszająca wszystkich, towarzyszące temu procesje (Bachtin, 1975, ss.150, 333), maski (Bachtin, 1975, s. 103) i przebrania (Bachtin, 1975, s. 155). Kulturowo ujmując, nie są to tylko aspekty techniczne, lecz immanentne elementy karnawału, które stają się w tej obrzędowości znakami-symbolami.

Właściwa karnawałowi cykliczność wynika z jego związków z czasem, dlatego karnawał jest „świątecznym śmiechem z czasem i ze zmianami czasowymi", a nie tylko egzemplifikacją jakiegoś aspektu cykliczności pór roku. Ten związek karnawału z czasem symbolizuje także - jak przekonuje Bachtin ludowe marzenia o lepszym życiu, i o lepszej przyszłości. Być może dlatego karnawał ma w zwyczaju „spoglądać w przyszłość śmiejąc się na pogrzebie przeszłości i teraźniejszości” (Bachtin, 1975, s. 155). To stąd również karnawał triumfalnie, choć chwilowo, uwalnia od panującej prawdy (Bachtin, 1975, s. 67), gdyż tylko świat chwilowo uwolniony daje się na nowo odkryć we wspólnej zabawie i wspólnym śmiechu (Bachtin, 1975, s. 159).

Jakkolwiek karnawał „uwalnia” od przeszłości i teraźniejszości, to jednak jego badanie z konieczności powinno uwzględniać historyczność, a więc czas i miejsce, w którym karnawał i towarzyszący mu śmiech karnawałowy (kultura śmiechu) pojawiają się, rozwijają i obumierają (Bachtin, 1975, s. 227). Każda epoka wytwarza właściwą sobie - w obrębie swej powszechności, uniwersalności i światopoglądu - strukturę, esencję i funkcję karnawału, a także śmiechu. Nie można więc w badaniach tych fenomenów przyjmować ich ahistoryczności i koncentrować się zaledwie na ich technicznych aspektach (Bachtin, 1975, s. 218). Nie można też - a badania Bachtina są tego dowodem - sprowadzić karnawału i śmiechu zaledwie do peryferyjnych zjawisk społecznych, kulturowych i estetycznych, tylko dlatego, że karnawał i śmiech karnawałowy są „jakoś” kulturze ludu właściwe. Bachtin zresztą zauważa, że niejako metodologicznym błędem jest niedocenianie roli ludu w formowaniu radykalnych wizji świata, które przecież prezentują interesy i myśli ludzi (Bachtin, 1975, ss. 221-222). W swej naturze wizje te są całościowe, choć ludowe. W tym przypadku karnawał byłby niczym innym jak obrazo- 
waniem właśnie radykalnej (?), ludowej wizji świata. Dlatego celem badania karnawału powinno być badanie karnawału jako „odczuwanie świata”, i jako „uniwersalność świata”, badanie zaś śmiechu powinno ujmować „śmiech jako aspekt świata" (Bachtin, 1975, s. 218). Inaczej ujmując, chodziłoby o funkcję karnawału i funkcję śmiechu karnawałowego w kulturze i życiu.

Badanie karnawału, podobnie jak badanie śmiechu (kultury śmiechu), powinno wobec tego uwzględniać nie tylko aspekt społeczny, ale także historyczne przemiany w tym obszarze. Jego istotą jest nie tylko - jakby można dziś powiedzieć - deskryptywne ujęcie karnawału, ale także historyczne wyjaśnienie znaczenia śmiechu i właściwych karnawałowi form obrzędowo -widowiskowych (Bachtin, 1975, s. 218). Jest to istotne metodologiczne wskazanie, gdyż bez badania tradycji (Bachtin, 1975, s. 195), która doprowadziła do wykształcenia określonych form karnawału nie jest możliwe zrozumienie światopoglądu śmiechu i obecnego w nim aspektu uniwersalności (Bachtin, 1975, s. 217). Zwykle bowiem badania tzw. folkloru śmiechu - jak pisałam - nie wykraczają poza ramy kultury oficjalnej. Tymczasem śmiech zwykle wykracza poza ramy tego, co oficjalne (Bachtin, 1975, s. 222).

\section{Wytwarzanie tradycji: „dzieje stroju kaszubskiego”}

Opowieść o dziejach stroju kaszubskiego ukryta jest m.in. w publikacjach Bożeny Stelmachowskiej, autorki „Atlasu Polskich Strojów Ludowych. Pomorze: Strój kaszubski” (1959) i publikacji Franciszka Kwidzińskiego „Kaszubskie stroje ludowe" (1998). Omawiając strój ludowy, Kwidziński przypomina ważką informację z dziejów kartuskiego zespołu folklorystycznego „Kaszuby”, pisząc, że do 1945 roku kaszubski strój ludowy nie był dokładnie opisany, a jego dokładny opis pojawia się dopiero w roku 1954.

Kwidziński pisze też, że w 1953 roku Ministerstwo Kultury i Sztuki w Warszawie przysłało do Kartuz podległy mu zespół etnografów (wśród nich była Stelmachowska). Zadaniem zespołu było „ustalenie dokładnego wzoru stroju kaszubskiego”. Efektem prac był tom „Strój kaszubski” w ramach cyklu „Atlas Polskich Strojów Ludowych”, a także opracowanie wzoru kaszubskiego stroju ludowego. Ważnym wydarzeniem - jak można wnioskować z tekstu - w dziejach zespołu „Kaszuby” było podarowanie w 1954 roku przez Ministerstwo 12 strojów kobiecych i tyle samo męskich. Kwidziński dodaje, że dzisiejsze stroje ludowe zespołu niewiele różnią się od tych, które zaprojektowane zostały przez etnografów na początku lat 50. (Kwidziński, 1998, s. 7-8). Można przypuszczać, że zakończenie prac nad wzorem kaszubskiego 
stroju ludowego było ważkie, skoro znalazła się o tym wzmianka w „Głosie Wybrzeża". Napisano tam:

„Oba zespoły kościerski i kartuski nie mogą występować publicznie, gdyż po 9 latach zażartych dyskusji »znawcy« nie potrafili definitywnie określić, jak powinien wyglądać ludowy strój kaszubski. Dopiero niedawno Ministerstwo Kultury i Sztuki oraz muzeum kultur ludowych zatwierdziły projekt opartego na starannych badaniach etnograficznych stroju regionalnego" ([b/a] (1954).

Jedną z osób, które wzięły udział w badaniach terenowych - jak pisał Kwidziński - była Stelmachowska. W wyniku badań doszła ona do kilku ważkich wniosków: po pierwsze, istniały trzy typy stroju kaszubskiego: ludności rolniczej [chłopskiej - uwaga A.K.], rybaków nadmorskich i kaszubskiej podmiejskiej ludności Gdańska (Stelmachowska, 1959, s. 6). Po drugie, specyfika stroju kaszubskiego jest „wcale wyraźna”, wyraźny jest podział na strój wiejski i podmiejski gdański (Stelmachowska, 1959, s. 12). Po trzecie, strój kaszubski nie był tylko jednokolorowy (granatowy, jak sądzono), jednakże jego charakterystyczną cechą jest „brak wystroju”, co oznacza, że nie posiadał on haftów, ozdób, naszywków. Posiadał jednak specjalny układ barw i kształt, co różniło go od strojów sąsiadów (Stelmachowska, 1959, s. 12). Po czwarte, na początku lat 50. strój ludowy na Kaszubach nie istniał we właściwym tego słowa znaczeniu, choć badaczka dostrzegła „resztki męskiego roboczego stroju ludowego”. A także - jak pisała - „widuje się w niedzielę, święta i przy uroczystościach państwowych kaszubski strój w grupach młodzieżowych”. Był to jednak strój świetlicowy (Stelmachowska, 1959, s. 13). Po piąte, strój świetlicowy „nie przeniósł się (...) bezpośrednio z chałupy na estradę muzyczną, czy taneczną, jak w wielu innych regionach Polski, ale powstał pośrednio drogą rekonstrukcji” (Stelmachowska, 1959, s. 13). Po szóste, podstawą rekonstrukcji powinny być wspomnienia ludu [wywiady ustne - uzupeł. A.K.] dotyczące problemu rekonstruowanego. Jednak Kaszubi biorący udział w badaniach nie potrafili odróżnić typowych cech dla kaszubskiego stroju ludowego od jego cech przypadkowych (Stelmachowska, 1959, s. 13). Dokładne przedstawienie stroju kaszubskiego (do końca XIX wieku) jest trudne, gdyż nie zachowały się żadne jego resztki, kompletnego stroju nie posiada też żadne muzeum (Stelmachowska, 1959, s. 25). Po siódme, od II połowy XIX wieku zanika strój ludowy na Kaszubach (wschodnich). Stelmachowska stawia tezę, że zachowane opisy dotyczą nie rozkwitu, ale jego zmierzchu (Stelmachowska, 1959, s. 67). Po ósme, strój świetlicowy jest próbą rekonstrukcji stroju ludowego, 
którego podjęła się Franciszka Majkowska. Pierwsza jego prezentacja odbyła się w 1910 roku w trakcie wieczornicy Towarzystwa Czytelni Polskich w Kościerzynie. Od tego czasu strój świetlicowy używany był w wiejskich teatrach amatorskich i dorocznych uroczystościach. Stelmachowska pisze, że najbardziej przyjęła się wersja stroju świetlicowego opracowana przez Majkowską. Po dziewiąte, między rokiem 1910 a początkiem lat 50. XX wieku wykrystalizował się ostateczny wzór paradnego stroju kaszubskiego (Stelmachowska, 1959, s. 14).

Trzeba jednak dodać, że o ostatecznym wzorze stroju ludowego nie zdecydowali sami Kaszubi, ale etnografowie, którzy od 1945 roku pracowali nad jego rekonstrukcją, a właściwie nad jego przystosowaniem do wzorca polskich strojów ludowych. Stelmachowska zwraca uwagę, że wersja świetlicowa opracowana przez Majkowską „obowiązywała” do początku lat 50. Wypracowana przez etnografów polska wersja stroju kaszubskiego weszła w życie kaszubskie po zatwierdzeniu przez Ministerstwo Kultury i Sztuki. Druga ważna informacja, to ta, że hafty kaszubskie nie miały żadnej tradycji w ludowości kaszubskiej, i że dopiero od 1906 roku zaczęto nimi ozdabiać zapaskę w stroju kobiecym. Haft kaszubski wypracowała Teodora Gulgowska, która na technikę hafciarską przetworzyła „motywy zabytkowej kaszubskiej ornamentyki malowanej lub rytowanej" (Stelmachowska, 1959, s. 14).

Tak więc nie tylko kaszubski strój ludowy jest tym, co nazwać można „tradycją wynalezioną" w rozumieniu Hobsbawna (2008), ale i haft kaszubski, także ten na strojach ludowych, jest „tradycją wynalezioną”. O ile jednak strój kaszubski w jego wersji świetlicowej jest wynalazkiem kaszubskim, o tyle haft jest efektem pracy etnografki, bo nią niewątpliwie - mimo braku kierunkowego wykształcenia - była Teodora Gulgowska, i to również dzięki niej haft "zawędrował" na świetlicowy strój kaszubski.

Stelmachowska w tomie „Strój kaszubski” nie pisze jednak o bezpośredniej przyczynie zaangażowania etnografów w prace nad strojem kaszubskim. Jak wynika z tekstów Stelmachowskiej, władza komunistyczna w latach 40. i 50. postawiła nowe zadania przed polską etnografią. O ile starym, tradycyjnym zadaniem etnografii jest badanie przeszłości i teraźniejszości, o tyle owym nowym wyzwaniem stało się współdziałanie w planowaniu kulturowym i rzutowaniu w przyszłość. „Jest to nowość - pisała w 1946 roku Stelmachowska - ale nowość nie podlegająca dyskusji, ponieważ w oczach naszych staje się faktem dokonanym. Trzeba się do niej dostosować w imię potrzeb wielkiej wagi. Zadanie to jest zresztą fascynujące" (Stelmachowska, 1946a, s. 9). „Nowe” podejście metodologiczne w etnografii stanowiło, że na 
starych ziemiach obowiązywały metody „konserwacji i rekonstrukcji kultury ludowej”, na nowych (Ziemie Odzyskane) „odnajdywanie i zaszczepianie” tej kultury (Stelmachowska, 1946a, s. 9).

Stelmachowska miała plan także w stosunku do Kaszubów, których kultura musiała siłą rzeczy wpisać się ogólne tezy polityki kulturowej (tożsamościowej) wczesnego PRL (por. Kożyczkowska, 2015). Ówczesna sztuka ludowa - bo chyba tylko tak widziała Stelmachowska kaszubskość - była po pierwsze zachwaszczona wpływami niemieckimi, i po drugie, powinna rzutować w przyszłość, czyli powinny w niej narastać wpływy polskie. Tam gdzie kaszubszczyzna zanikła w terenie, powinna ona ożyć na nowo. Stelmachowska widziała dwa jądra promieniowania kaszubszczyzny: pierwszym było Wejherowo, Żarnowiec i Żukowo, stąd kaszubszczyzna miała promieniować na północy Kaszub; drugim - Kartuzy, Kościerzyna i Chojnice, a stąd kaszubszczyzna miała promieniować na południu Kaszub (Stelmachowska, 1946a, ss. 15-19).

Strój ludowy jest ważnym elementem tożsamościowym, gdyż symbolizuje on kulturę polską. Dlatego też, zdaniem Stelmachowskiej, o stroju ludowym w polityce kulturowej nie można zapomnieć (Stelmachowska, 1946a, s. 19). Autorka daje więc praktyczną wskazówkę, jak powinna przebiegać jego reaktywacja także na Kaszubach:

„Etnograf musi dostarczyć teatrom, świetlicom, organizacjom na zachodzie materiału ilustracyjnego z typologii regionalnej. Pod jego nadzorem artyści i technicy zrekonstruują dla Pomorza Zachodniego strój kaszubski i kociewski (...)" (Stelmachowska, 1946a, s. 20).

Wypracowanie metodyki reaktywacji polskiego stroju ludowego miało na celu wypracowanie podstaw dla reaktywacji także innych działów polskiej sztuki ludowej (Stelmachowska, 1946a, s. 20). Sama zaś kultura kaszubska, jako właśnie kultura polska i słowiańska zarazem, była rozumiana jako kultura prawowitych mieszkańców, bo Polaków i Słowian, i miała być wykorzystana jako czynnik spajający Pomorze. Wymagało to jednak zorientowania się w dyrektywach „repolonizacji współczesnej” (Stelmachowska, 1946b, s. 981-982) i wymagało - jak dowodziła Stelmachowska - diagnozy w zakresie obecności kultury polskiej w przeszłym i teraźniejszym życiu Kaszubów. Celowo używam przymiotnika „polskiej”, gdyż zadaniem etnografii w czasach wczesnego PRL było udowodnienie polskości (i słowiańskości) Ziem Odzyskanych (por. Wróblewski, 2004, s. 224) i zapewne innych, na których przed pierwszą wojną światową były silne wpływy niemieckie. 
Misją etnografów było więc działanie na rzecz polityki ludnościowej wczesnego PRL. Dlatego zapewne sama Stelmachowska rozumiała etnografię jako dyscyplinę użyteczną nowej polityce tożsamościowej, i dlatego widocznie poszerzyła jej przedmiot badania o projektowanie przyszłości. Logicznym zatem jest to, że etnografia miała „konserwować i konstruować” kulturę ludową, ale jednocześnie tam, gdzie trzeba było ją „wynaleźć” na nowo, etnografia miała „odnajdywać i zaszczepiać” (Stelmachowska, 1946a, ss. 9-21. Stelmachowska, 1946b, ss. 979-985. Kwaśniewska, 2009, ss. 267-368). Stelmachowska ten proces „odnajdywania i zaszczepiania” nazwała „kolonizowaniem” (Stelmachowska, 1946b, s. 979).

Domykając wątek, trzeba dopowiedzieć, że kaszubski strój ludowy, jakkolwiek jest wynaleziony przez Kaszubów na nowo, na początku XX wieku, to został on skorygowany do polskości przez etnografów w latach 40 . i na początku lat 50. XX wieku i po ostatecznym zatwierdzeniu przez władzę komunistyczną wczesnego PRL, został (od)dany w użytkowanie Kaszubom. Na początku XXI wieku można właściwie uznać, że projektowany przez Stelmachowską proces „odnajdywania i zaszczepiania” stroju ludowego na Kaszubach został ukończony, i to z powodzeniem. Nie tylko bowiem udało się sprawić, że kaszubski strój ludowy, który wszedł na estradę w 1910 roku, „nie z chałupy” - jak pisała Stelmachowska - ale pośrednio, w wyniku starań wielu osób, które taki kaszubski strój ludowy chciały mieć; nie tylko strój kaszubski przetrwał na estradzie kolejne dziesięciolecia, ale jeszcze „zszedł z estrady" i spowodował, że niektórzy Kaszubi chętnie zaczęli się w niego przebierać. Taki stan rzeczy z pewnością uznać trzeba za zwycięstwo polityki tożsamościowej wczesnego PRL i tym samym za zwycięstwo ówczesnej etnografii. W ten oto sposób dokonała się kolonizacja Kaszubów, o której pisała Stelmachowska.

\section{Wynajdywanie kaszubszczyzny: próba konkluzji}

(Re)tradycjonalizm kaszubski, który obrazują dwa ostatnie podręczniki Pioch, a także podręcznik Pryczkowskiej i Hewelt, nie jest dowodem na to, że autorki uknuły kulturowy spisek. I nie jest dowodem na to, że Pryczkowska i Hewelt postanowiły skonstruować kaszubszczyznę na nowo, na wzór Bachtinowskiego „świata na opak” (Bachtin, 1975, s. 68), a „karnawalizacją” oczarować umysły i serca młodych Kaszubów. A wszystko po to, by w określony sposób (u)kształtować ich kulturową tożsamość wedle modelu nowej ludowości. Jest absolutnie inaczej, te podręczniki odzwierciedlają obecną w kaszubskiej przestrzeni 
publicznej praktykę, która realnie dzieje się w wielu środowiskach kaszubskich i jest alternatywą dla poważnej, bo intelektualnej (Bobrowski, Kwiatkowska, Labudda, Czerwińska, Pająk, Sorn) albo pobożnej (Pioch) kaszubszczyzny.

Szczególnie podręcznik Pryczkowskiej i Hewelt, jako najmłodszy z grupy podręczników, stanowi cenny materiał w badaniach kultury kaszubskiej, nie tylko w dociekaniach pedagogicznych i edukacyjnych. Tego typu podręczniki są cennym źródłem wiedzy także dla innych badaczy nauk społecznych i humanistycznych. W problematyce niniejszego artykułu przyjęłam, że można je traktować jako materiał empiryczny dla potrzeb badania tego, co tu nazwałam „tradycją wynalezioną".

„Tradycja wynaleziona” to według słów Hobsbawma zespół działań o charakterze rytualnym lub symbolicznym, który został jawnie bądź skrycie wprowadzony w praktykę społeczną. „Tradycja wynaleziona” ma do spełnienia dwa podstawowe zadania: nasączyć umysły wspólnoty nowymi wartościami i normami, a także zmodyfikować/wytworzyć nową przeszłość, w której „znajdą się argumenty” na rzecz nowej teraźniejszości (Hobsbawm, 2008, s. 9). Chodzi więc nie tyle o technikę zachowań społecznych, lecz o ich warstwę symboliczną i ideologiczną. W ten sposób „wynaleziona tradycja” ma stać się nowym zasobem wiedzy bądź ideologii narodu, państwa, wspólnoty (Hobsbawm, 2008, s. 20), albo - jak się zdaje - jednym i drugim. Jak się wydaje, „wynaleziona tradycja” jest użyteczną metodą wytwarzania więzi wspólnotowych, na poziomie afektywnym i poznawczym. Jednostki zwykle czują i myślą inaczej niż wspólnoty, narody, a nawet państwa. Wiedza narodowa czy wspólnotowa jest w sposób szczególny selekcjonowana, nie tylko po to, by wiedzieć o swoich tak samo, jak wszyscy, ale by dodatkowo czuć wobec swojej wspólnoty tak samo jak czują wszyscy.

W tym znaczeniu „tradycja wynaleziona” należy do tej grupy praktyk kulturowych, które są jednocześnie praktykami edukacyjnymi, a ich rzeczywistym zadaniem jest wytwarzanie emocjonalnego stosunku do własnej wspólnoty/narodu. „Wynajdywanie tradycji” jest wobec tego symptomatyczne - jak przekonuje Hobsbawm - dla tych sytuacji społecznych, które osłabiają lub niszczą wzory społeczne, według których „zaprojektowane zostały »dawne « tradycje" (Hobsbawm, 2008, s. 13).

Można więc potraktować ostatnie podręczniki Pioch i podręcznik Pryczkowskiej i Hewelt jako symptom (a więc i wskaźnik) kulturowej kondycji Kaszubów. Zresztą diagnoza kultury kaszubskiej została przedstawiona przez Pryczkowską i Hewelt już we wstępie do ich podręcznika. Autorki piszą: 
„Kaszëbizna je jak nen mòtil ùtacony w jantarze, przësnôżi, leno cãżkò mù je sã dzwignąc, rozwinąc lecëdła i pòlecec widzało kãdës dalek. Blós młodé pòkòlenié mòże ten skôrb wëdwignąc. [Kaszubszczyzna jest jak motyl ukryty w bursztynie, przepiękny, lecz trudno mu się podnieść, rozpostrzeć skrzydła i polecieć dostojnie gdzieś daleko. Tylko młode pokolenie potrafi ten skarb unieśćc" (Prëczkòwskô i Héwelt, 2015, s. 5).

Metafora „motyla ukrytego w bursztynie”, jakkolwiek poetycka, jednak jest dość ryzykowna dla zobrazowania żywotności kultury kaszubskiej czy nawet prób jej resuscytacji. Problem bowiem w tym, że „motyl w bursztynie” to zaledwie skamielina, co prawda gratka dla paleontologów, a właściwie paleozoologów, czy też jubilerów i ich klientów, niemniej jednak chodzi o martwego owada. Kłopotliwość metafory jest tym większa, że przecież człowiek nie ma mocy ożywienia tego, co umarłe, zwłaszcza/nawet jeśli to zmarło kilka tysięcy lat temu. Człowiek może badać skamieliny, zachwycać się ich pięknem, ale może tylko stworzyć warunki, by jakieś życie urodziło się i przeżyło swój żywot jeden raz.

Jest w tej metaforze kaszubszczyzny ta sama groza martwego ciała, z jaką ma się do czynienia u Gunthera von Hagensa, gdy „konstatuje się” jego „dzieła”, czyli martwe i poddane plastynacji ludzkie ciała. Hagens za pomocą określonego polimeru sprawia, że ukryte w śmierci ciało człowieka „rozpościera” swe przepiękne mięśnie i ścięgna, i „leci” gdzieś w dal, z jednej ekspozycji na drugą. Trzeba przyznać, że jest w tym „świecie na opak” magia i ciekawość, która skłania ludzi do oglądania i popadania w zachwyt, ale jest i groza, i oburzenie.

Być może jest tak, że niektórzy Kaszubi mają przeświadczenie (przeczucie), że ich kultura obumarła. Z przestrzeni publicznej zniknął przecież język kaszubski. Z wielu domów także zniknął język kaszubski, a jego pokoleniowa socjalizacja właściwie nie istnieje. Szkoła także nie spełniła swego zadania, gdyż po ćwierćwieczu edukacji kaszubskiej w szkole Kaszubi są nadal niemi w mowie swych ojców. Niektórzy potrafią mówić po kaszubsku, niektórzy biernie rozumieją swą mowę, ale większość z nich to analfabeci w swoim ojczystym języku. Religijność Kaszubów jest tak samo wątpliwa jak religijność wielu innych obywateli w Polsce, więc nie może być ona uznana za potencjał działań związanych z ratowaniem kaszubszczyzny.

Zwyczajnych Kaszubów zawiedli i ci wykształceni, i ci pobożni. Pozostało więc to, co najprostsze do realizacji: ludowość. Ale „dawna” ludowość nie potrafi wygenerować więzi wspólnotowych, gdyż jest tak samo martwa, jak cała kaszubszczyzna w diagnozie Pryczkowskiej i Hewelt. Wobec tego nowe - ludowe - elity kaszubskie zaczęły korzystać z dostępnych zasobów kaszubskich, czyli przykładowo ze strojów ludowych, wymyślonych w między- 
wojniu i zmodyfikowanych przez komunistyczną politykę tożsamościową do polskich strojów ludowych. Trzeba jeszcze było wynaleźć stosowne sytuacje społeczne, w których mogłyby się pojawiać - właściwe karnawałowi - formy nowej ludowości, a więc przykładowo Zjazdy Kaszubów. Tyle tylko i aż tyle trzeba zrobić, aby wynaleźć kaszubszczyznę na nowo.

\section{Bibliografia}

[b/a], (1954). Czekamy na utworzenie Państwowego Regionalnego Zespołu Pieśni i Tańca „Kaszuby”. Głos Wybrzeża. Pismo Polskiej Partii Robotniczej. 62, s. 6.

Bachtin, M. 1975. Twórczość Franciszka Rabelais'go a kultura ludowa średniowiecza i renesansu. Kraków: Wydawnictwo Literackie.

Bòbrowsczi, W. i Kwiatkòwskôko, K. 2007. Kaszëbsczé abecadto. Twój pierwszi elemeńtôrz. Gdańsk: Wydawnictwo Jaskółka, Wydawnictwo DJ.

Czerwińska, T., Pająk, A. i Sorn, L. 2007a. Z kaszëbsczim w szkòle. Podręcznik pomocniczy do nauczania języka kaszubskiego w klasach I-III. Czãsc 1. Gduńsk: Wydawca Zrzeszenie Kaszubsko-Pomorskie Zarząd Główny.

Czerwińska, T., Pająk, A. i Sorn, L. 2007c. Z kaszëbsczim w szkòle. Podręcznik pomocniczy do nauczania języka kaszubskiego w klasach I-III. Czãsc 3. Gduńsk: Wydawca Zrzeszenie Kaszubsko-Pomorskie Zarząd Główny.

Czerwińska, T., Pająk, A. i Sorn, L. 2009. Z kaszëbsczim w szkòle. Podręcznik pomocniczy do nauczania języka kaszubskiego w klasie IV. Czãsc II. Gduńsk: Wydawca Zrzeszenie Kaszubsko-Pomorskie Zarząd Główny.

Czerwińska, T., Pająk, A. i Sorn, L. 2007b. Z kaszëbsczim w szkòle. Podręcznik pomocniczy do nauczania języka kaszubskiego w klasach I-III. Czãsc 2. Gduńsk: Wydawca Zrzeszenie Kaszubsko-Pomorskie Zarząd Główny.

Foucault, M. 1993. Nadzorować i karać. Narodziny więzienia. Warszasza: Wydawnictwo Aletheia-Spacja.

Gramsci, A. 1991. Zeszyty filozoficzne. Warszawa: Wydawnictwo Naukowe PWN, Warszawa.

Hobsbawm, E. 2008. Wprowadzenie. Wynajdywanie tradycji. W: Hobsbawm, E. i Ranger, T. red. Tradycja wynaleziona. Kraków: UJ, ss. 9-23.

Kożyczkowska, A. 2015. Od praktyki do teorii edukacji regionalnej. Casus kaszubskości. W: Kossak-Główczewski, K. i Kożyczkowska, A. red. Wielokulturowość: między edukacją regionalną i edukacją międzykulturową. Dylematy $i$ konteksty tożsamościowe. Kraków: Oficyna Wydawnicza „Impuls”, ss. 51-83. 
Kożyczkowska, A. 2016. Podręcznik jako (nie)możliwy projekt tożsamościowy. Przypadek jednego podręcznika do edukacji kaszubskiej. Acta Universitatis Nicolai Copernici. Pedagogika. 32, ss. 87-114.

Kwaśniewska, A. 2009. Badania etnologiczne na Kaszubach i Pomorzu Wschodnim w XIX $i$ XX w. Ludzie, instytucje, osiagnięcia badawcze. Gdańsk: Instytut Kaszubski.

Kwidziński, F. 1998. Kaszubskie stroje ludowe. Kartuzy: Zespół Pieśni i Tańca „Kaszuby” w Kartuzach.

Labudda, J. 2007. Zôrno mòwë. Pòdrãcznik do úczbë kaszëbsczégo jãzëka dlô pòczatkùjącëch (kl. IV-VI). Dzél I. Gdańsk: Zrzeszenia Kaszubsko-Pomorskiego Zarząd Główny.

Labùdda, J. 2010. Zdrój słowa. Pòdrãcznik do úczbë kaszëbsczégo jãzëka dlô pòczatkùjacëch (kl. IV-VI). Dzél II. Gdańsk: Zrzeszenia Kaszubsko-Pomorskiego Zarząd Główny, Gdańsk.

Lessnau, P. 2007. Kaszëbsczé kabaretë. Stegna. 1, s. 7.

Mazurek, M. 2010. Język, przestrzeń, pochodzenie. Analiza tożsamości kaszubskiej. Gdańsk: Instytut Kaszubski.

Pająk, A. i Sorn, L. 2015. Z kaszëbsczim w szkòle. Podręcznik pomocniczy do nauczania języka kaszubskiego w klasie V. Część 3. Gduńsk: Zrzeszenie Kaszubsko-Pomorskie Zarząd Główny.

Pioch, D. 2005. Najô domôcëzna. Üczbòwnik z cwiczënkama do nôùczi kaszëbsczégò jãzëka. Dzél III. Banino-Pelplin Gdańsk: Zrzeszenie Kaszubsko-Pomorskie Zarząd Główny.

Pioch, D. 2007. Żëcé codniowé na Kaszëbach. Ùczbòwnik do nôùczi kaszëbsczégò jãzëka. Dzél II. Gdańsk: Zrzeszenie Kaszubsko-Pomorskie Zarząd Główny.

Pioch, D. 2011a. Òjczëstô mowa. Ùczbòwnik do nôùczi kaszëbsczégò jãzëka w I klase gimnazjum. Gduńsk: Zrzeszenie Kaszubsko-Pomorskie Zarząd Główny.

Pioch, D. 2011b. Z kaszëbsczim w swiat. Ùczbòwnik do kaszëbsczégò jãzëka dlô I etapù sztôtceniô. Gduńsk: Zrzeszenie Kaszubsko-Pomorskie Zarząd Główny.

Pioch, D. 2011c. Kaszëbë. Zemia i lëdze. Ùczbòwnik do kaszëbsczégò jãzëka. Gduńsk: Zrzeszenie Kaszubsko-Pomorskie Zarząd Główny.

Pioch, D. 2000. Kaszëbë. Zemia i lëdze. Podręcznik języka kaszubskiego z ćwiczeniami. Część I. Gdańsk: Zrzeszenie Kaszubsko-Pomorskie Zarząd Główny. 
Prëczkòwskô, E. i Héwelt, J. 2015. W jantarowi krôjnie. Ùczbòwnik do kaszëbsczégò jãzëka dlô gimnazjum. Dzél I. Gdunsk: Zrzeszenie Kaszubsko-Pomorskie.

Rompski, J. 1973. Ścinanie kani: kaszubski zwyczaj ludowy. Toruń: Muzeum Etnograficzne w Toruniu.

Stelmachowska, B. 1946a. O styl i obyczaj rodzimy na Ziemiach Odzyskanych. Przeglad Zachodni. 1, ss. 9-21.

Stelmachowska, B. 1946b. Polska kultura ludowa czynnikiem zespalającym Ziemie Odzyskane. Przeglad Zachodni. 12, ss. 979-985

Stelmachowska, B. 1959. Atlas Polskich Strojów Ludowych. Pomorze: Strój kaszubski, Część 1, Zeszyt 2. Wrocław: Nakładem Polskiego Towarzystwa Ludoznawczego we Wrocławiu.

Wróblewski, W. 2004. Badania etnograficzne w województwie koszalińskim w latach 1950-1975. Stupskie Studia Historyczne. 11, ss. 223-242.

Treder, J. red. 2012. Zwyczaj $i$ widowisko Ścinania kani w etnologii i literaturze. Wejherowo: Muzeum Piśmiennictwa i Muzyki Kaszubko-Pomorskiej.

\title{
Kashubian (re)traditionalism: towards new folklore
}

\begin{abstract}
The paper is an attempt to recognise a Kashubian-related practice of (re)traditionalism recognised as "new folksiness". The most visible exemplifications are a parade, a folk costume and Kashubian embroidery, which aesthetise the public space of mass events such as the Kashubian Convention or General Meetings of the Kashubian and Pomeranian Association. The subject of empirical exploration are textbooks for Kashubian education. On their basis the author has reconstructed the models of folkiness and has assumed as its indicator "the Kashubian parade folk costume". The context for interpretation is the concept of carnival by Michaił Bachtin.
\end{abstract}

Keywords: Kashubian culture, folk culture, carnival, Michaił Bachtin, textbooks, intercultural education

Translated by Adela Kożyczkowska 